Revue belge de géographie

3-4 | 2008

Formatting Europe - Mapping a Continent

\title{
The geographical Jeux de l'Oie of Europe
}

Les Jeux de l'Oie géographiques de l'Europe

\section{Adrian Seville}

\section{(2) OpenEdition}

\section{Journals}

\section{Electronic version}

URL: http://journals.openedition.org/belgeo/11907

DOI: 10.4000/belgeo.11907

ISSN: 2294-9135

\section{Publisher:}

National Committee of Geography of Belgium, Société Royale Belge de Géographie

\section{Printed version}

Date of publication: 31 December 2008

Number of pages: $427-444$

ISSN: 1377-2368

\section{Electronic reference}

Adrian Seville, "The geographical Jeux de l'Oie of Europe", Belgeo [Online], 3-4 | 2008, Online since 22 May 2013, connection on 05 February 2021. URL: http://journals.openedition.org/belgeo/11907 ; DOI: https://doi.org/10.4000/belgeo.11907

This text was automatically generated on 5 February 2021.

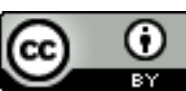

Belgeo est mis à disposition selon les termes de la licence Creative Commons Attribution 4.0 International. 


\title{
The geographical Jeux de l'Oie of Europe
}

\author{
Les Jeux de l'Oie géographiques de l'Europe
}

Adrian Seville

\section{Scope of the paper}

1 The title of the paper is perhaps controversial. On the one hand, geographical games that are strictly based on the traditional Jeu de l'Oie with rules identical in all respects are nowhere to be found. On the other, if the term Jeu de l'Oie is applied in the widest sense, meaning any sort of game of chance, then the subject becomes diffuse. The paper concentrates on those geographical games that are recognisably connected, through their rules, with the traditional Jeu de l'Oie. (For discussions on rule variations, see Seville (1991) and Zollinger (2003)). Accordingly, the games treated here are all (except one included as a comparison) single-track race games of pure chance, using dice or their equivalent to determine the movement of tokens along the track towards a finishing space.

2 The term "geographical" refers to the thematic aspect of the game. However, though games with a geographic theme often use maps structurally, this is not universal. For example, games on the "world tour" theme often show illustrations of the places visited rather than a map. This paper is primarily concerned with map-based (cartographic) games.

3 Even within the class of map-based games, a number of different sub-classes may be identified. There are those in which the playing track is laid out on the face of a single map, while others provide a separate track; or the track itself may consist of numerous small maps. The map may be in outline or relief and may be illustrated, for example with vignettes characteristic of each place, or may bear text characterising those places. Map games thus demonstrate considerable variety in appearance, even without taking into account the usual differences in printing processes, colouring, format etc. found in cartographic studies generally. There is also considerable variety in how 
"real" they are. In some games, the track represents an actual voyage rather than a supposed journey - for example, Stanley's March across the Dark Continent for the Relief of Emin Pasha (Royal Museum for Central Africa, Tervuren, shelf mark 74.53). Or it may represent the travels of a fictional character. Indeed, the territory "represented" by the map may be entirely of the imagination - for example, the imaginary seascape in William Darton's game published in 1836: A Voyage of Discovery or the Five Navigators (Goodfellow, 1991, p. 40).

4 Most of the standard works on race games of the Jeu de L'Oie type include some brief account of geographical variants. Grand-Carteret (1896, pp. 257-256) includes a note on their history and development in his chapter on the game; see also Grand-Carteret (1895) and Rabecq-Maillard (1961, pp. 155-160). Whitehouse (1951, pp. 5-23) devotes a chapter to the English games of this genre in the Georgian and Victorian eras. D'Allemagne (1950, p. 46) in his book on the French Jeux de l'Oie gives a short note on the history of French geographical games, and Girard and Quétel do likewise (1982, p. 39). Mascheroni and Tinti (1981, p.78) mention Italian geographical games briefly. The Buijnsters (2005, pp.137-138) note various examples held in the Netherlands. However, no systematic treatment exists for the genre.

5 It is difficult to estimate the number of published map-based games. All lists must be regarded as incomplete, for it is inevitable that many games are lost over the years. Nevertheless, for the years to the end of the $19^{\text {th }}$ century, some indicative figures may be useful. Whitehouse (1951, pp. 5-23) gives 30 published in England to the end of the $19^{\text {th }}$ century. D'Allemagne (1950, pp. 218-219) lists 19 French games up to that date under the heading "Jeux à cartes geographiques", though these include one that is not a race game and five re-editions. The Buijnsters (2005) list perhaps another five published in the Netherlands, ignoring re-editions of French games. For Italy, Mascheroni and Tinti (1981) mention a few map-based games. The exhibition catalogues of the German collections (see for example Himmelheber (bayerische Nationalmuseum, 1972), Kohlmann (Museum für Deutsche Volkskunde, Berlin, 1978), and von Wilkens (Germanisches National Museum, Nürnberg, 1985)) indicate that mapbased games do not figure greatly in them until the end of the $19^{\text {th }}$ century, when an important sub-genre, typified by the title Tour of Switzerland, but including other "tours", began to appear: some of these were based on maps. For the proliferation of games in the $20^{\text {th }}$ century, including many hundreds of advertising and promotional games of an ephemeral nature, no useful numerical estimate of map-based games can be made, though they certainly figured significantly in the output. Indeed, a notable sub-genre encompasses map-games of geographical propaganda, showing the advance of armies, the extent of empire, or the sphere of influence generally (Milanesi, 1995).

6 The present short paper can cover only a small fraction of this material in detail. The focus is on games that have Europe as their theme or have an international dimension within Europe, giving insights into international relationships, perceptions - and misconceptions - at various points in history.

7 The end result of this narrowing of focus is the set of six games illustrated here. It includes some of the earliest and most interesting educational race games, spans four centuries, and presents games originating in five different countries of Europe. A number of other games are discussed briefly in the text. 


\section{The traditional Jeu de l'Oie}

8 The Jeu de l'Oie (Game of Goose, Gi(u)oco dell'Oca, Ganzenspel, Gänsespiel etc.) is historically the most important spiral race game ever devised. It has its roots in the Italy of Francesco de' Medici (1574-87), who, as Carrera (1617, p. 25) reports, sent it as a present to King Philip II of Spain. The game took hold there and elsewhere in continental Europe, where it is still played. It is played with double dice and the usual tokens, the aim being to arrive exactly at the final space, numbered 63 in the standard form of the game. Images of geese denote the favourable spaces. After landing on a goose, the player goes on by the amount of the throw. There are also unfavourable spaces, or hazards, which involve paying to the pool and other penalties. Most notable of these is death, on space 58: the unfortunate player who lands here must begin the game again. The other usual hazards are at 6 , a bridge - go on to $12 ; 19$, an inn - lose two turns; 31 , a well - wait until another reaches the space then exchange places; 42 , a maze - go back to 39 (usually); 52, a prison - wait as for the well. Being hit by another player's token involves changing places and paying to the pool. Winning requires the player to land exactly on space 63 - overthrows are counted backwards. This adds greatly to the excitement, since an overthrow may hit the "death" space. Indeed, the rules are ingeniously contrived to produce a highly playable game (Seville, 2001). Waiting in the prison or the well for some other unfortunate to arrive and take one's place is a chastening experience!

In this traditional form, the game was evidently a game of human life, with the geese evidently having a favourable symbolical significance (Domini, 1999, pp. 37-38). It was also imbued with numerological significance, deriving from the theories of the Cabala (Menestrier, 1704, p.196). This was a system of Jewish mystical theology developed in Spain in the $12^{\text {th }}-13^{\text {th }}$ centuries but then adapted for Christian use in the Renaissance, by Italian scholars especially (Blau, 1944). In this system, the number 63 was highly significant, representing the crucial year, or "grand climacteric", of life (Sir Thomas Browne, 1615, Ch XII).

10 At first sight, this background may seem irrelevant to the geographical variants. These variants have their own rules - why should a player be concerned with the details of a game he or she is not playing? However, this would be to ignore the fact that, for many players, the rules of the well-loved Jeu de l'Oie would be entirely familiar. A game that related to this would feel comfortable to play and - to the extent that the original rules were maintained - would benefit from the excitement and playability of the original game. Also, the significance of the playing spaces - especially the "good" spaces and the "bad" spaces - would carry over, either by direct reference or ironically. Indeed, this is a key feature of the many thousands of variants of the game produced on different themes throughout the centuries (Dietsch, 1983).

\section{The beginning: educational games in $17^{\text {th }}$ century France}

11 Educational games based on the Jeu de l'Oie for the teaching of geography were invented in France by Pierre Duval (1619-1683), well known for his educational maps. One of the distinguished school of French geographers initiated by Nicolas Sanson, he was 
appointed Géographe du Roi in 1650. His first game was Le Jeu du Monde. This was published in Paris in 1645 by Mariettte, who had previously published the earliest known French educational jeu de l'oie, the Jeu Chronologique, dated 1638. (D'Allemagne, 1950, p. 44). The Jeu du Monde had a spiral track made up of 63 circles, each being a small map of a different country of the world: the final winning circle represented France. There followed two other map games by Duval on a similar plan. First, Etienne Vouillement published Le Jeu de France in 1659, in which each circular space was a small map of a province of France (Seville, 2005). Then, in 1662, Nicolas Berey published Duval's Le Jeu des Princes de L'Europe. In this game, described in some detail below, each of the 63 circular spaces of the spiral track is a small map of a region or country of Europe, with France as the winning space. A map of Europe is in the centre.

Duval went to considerable lengths to produce games with the canonical number 63 as the winning space. His choice of the territories for the Europe game ("...each figure represents a Country, State or Island of this part of the world") may seem arbitrary but is directed to this end. For example, the first four spaces are labelled: Espagne, Castille, Arragon, Navarre; but then Portugal is given only a single space.

The general rules of the game are closely based on the Jeu de l'Oie:

Play with two common dice and 2, 3, 4, 5 or 6 players. Each plays once in turn, marking his place with a marker and moving according to the points on the dice. It is necessary to agree the stake: "un Icu, un Liard, un Sol, un Teston, une Pistolle", which each player must put on the Map of Europe in the centre. All the other payments are of the same value and all this is to the profit of the winner. To win the game, one must arrive exactly at France, the eye and pearl of the World and which is to Europe as Europe is to the other parts of the Earth. He who arrives there is master of all the payments, ransoms, lots, fines and other contributions.

Reverse overthrows are played, as in Goose. But then comes a special rule, which clearly indicates that Duval sees this as an educational game:

Who would take profit in Geography concerning Europe should take care to say the names of the places when he arrives and to read the names of the principal towns.

This approach also influences the cartography of the maps themselves: they are selective as to detail, concentrating on the key features of each territory.

The detailed "laws" of the game derive from those of the Jeu de L'Oie but are cleverly adapted to provide lessons in international relationships and perceptions of the period:

5 Portugal Stay to make the voyage to the East Indies until another player arrives and pays (the Goose Well rule).

6 Holande Embark at Flushing for Dover, No. 60 England, to assist in the marriage ceremonies of the King of Great Britain to the Princess of Portugal. (Similar to Goose rule for initial throw of 9).

10 Switzerland Stay to make a debauch with those of this nation and pay his scot, while the others play twice.

22 Sicily Shipwreck at the lighthouse of Messina, where the perils of Scylla and Charybdis used to be, and pays.

41 Denmark Must pay the tax to the Sund to dislodge the Hollandais who have lent money to the King during the war.

50 Muscovy Must advance once according to the points on the dice (a Goose rule). The Muscovites do not permit entry to their country, yet you pay. 
52 Hungary Receives from each player the agreed stake, for the fortification of the realm and to make levees against the Turk, meanwhile advancing to Transylvania, No 54.

57 Little Tartarie Must pay ransom in order not to be enslaved in Constantinople and must go to Spain No. 1 to begin the game again (compare the Goose death rule).

59 Candie Must be arrested to serve against the infidels and must stay until another takes his place (Goose prison rule).

Figure 1. Le Jeu des Princes de L'Europe - Pierre Duval (1662).

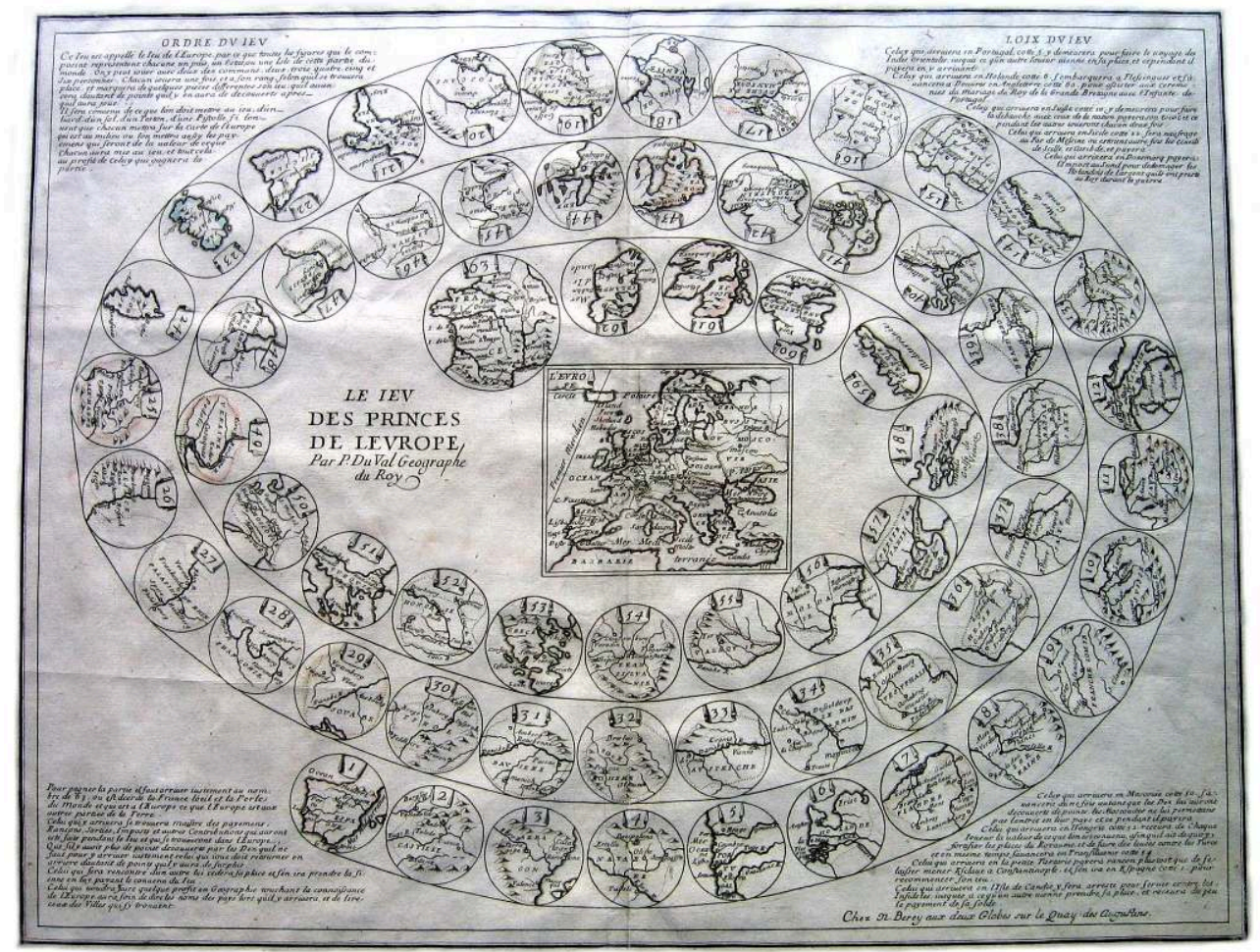

The entry for Holland is particularly interesting as it implicitly confirms the publication date of 1662: King Charles II of England married Catherine of Braganza, Infanta of Portugal, by proxy in Lisbon on $23^{\text {rd }}$ April 1662.

The overall effect is up-to-date and lively, suited to the intended market for the game: the young "cadets" of aristocratic families who were studying in Paris. As well as geography, their studies would include heraldry, history and the art of war, and their moral and spiritual development was not neglected. All these aspects of life are well represented in games of the period derived from the Jeu de l'Oie.

Duval himself produced a game on the conduct of war as early as 1660: Le Jeu des François et des Espagnols pour le Paix. This was also a spiral race game, but less closely based on the Jeu de l'Oie than those mentioned above. Again, circles containing individual maps were used, one for each year of the war from 1635 until the peace of 1660: each map showed the disposition of the French and Spanish forces in the particular year.

The legacy of the educational games invented in $17^{\text {th }}$ century France would continue there for more than three centuries, with continual updating and variation across themes both traditional and new. 


\section{English engraved games of the $18^{\text {th }}$ century}

\section{than in France (Shefrin, 1999). Whitehouse gives the first dated game of this kind as that invented by John Jefferys in 1759: A Journey through Europe, or the Play of Geography published by Carrington Bowles in London. The rules to be observed in the game begin: "The Journey through Europe is to be played in all respects the same as the Game of Goose. Whoever begins to spin the Totum first must place his man on the very number that turns up...".}

Figure 2. A Journey through Europe - John Jefferys (1759).

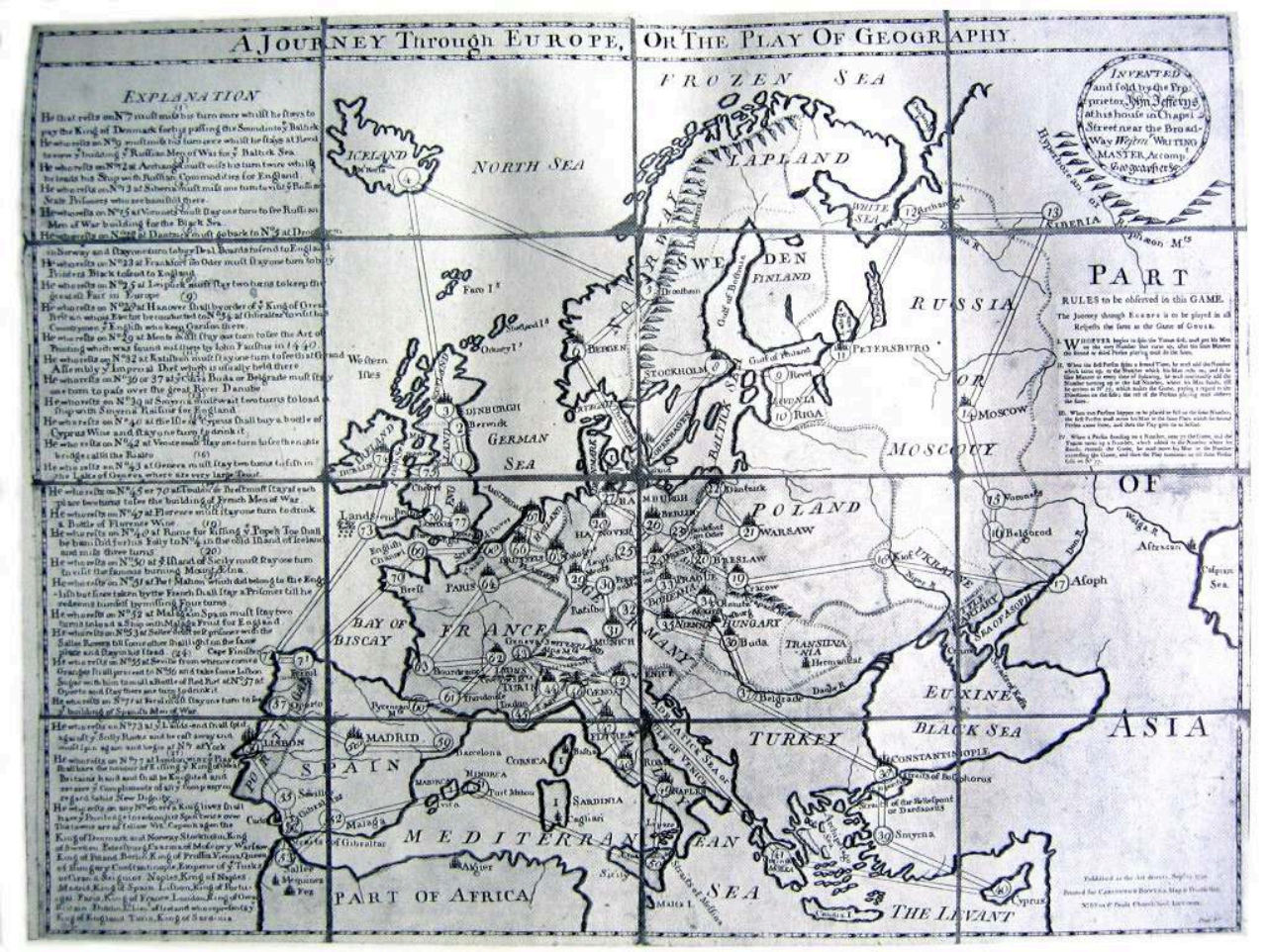

The "totum" (later known as the Teetotum) is a top-like spinner, used because in this period the use of dice was frowned upon, as associated with gambling and cheating. Jefferys does not specify how many sides the totum is to have. Versions numbered from 1 to 8 were common, but some games use a six-sided teetotum, to be spun twice, so giving the true effect of double dice. Twelve-sided versions were also in use.

The rules then explain how the next move is to be made by adding the next number spun, that the directions given for the various places encountered are to be followed, and that if the number spun carries a man past the winning space (London, at 77), the excess is to be counted negative - i.e., reverse overthrows are played, just as in the Game of Goose.

The Game of Goose was familiar and widely played throughout England, so Jefferys' reference to it is not surprising. His game is not of 63 spaces, suggesting that the numerological importance was lost on him. Nevertheless, the game has considerable structural similarity to the traditional Jeu de l'Oie. The chief characteristic of that game 
is the doubling forward of the throw when a goose space is encountered. In Jefferys' game, the equivalent spaces are "....any number where a King lives", and the player who lands on such a number has the privilege of reckoning his spin twice over. The places concerned are: Copenhagen (Denmark and Norway), Stockholm (Sweden), Petersburg (Czarina of Muscovy), Warsaw (Poland), Berlin (Prussia), Vienna (Queen of Hungary), Constantinople (Emperor of the Turks or Oran De Seignior), Naples (Naples), Madrid (Spain), Lisbon (Portugal), Paris (France), London (Great Britain), Dublin (Lord Lieutenant of Ireland who represents the King of England), Turin (Sardinia).

Unlike the Duval game, this is not a gambling game. There is no reference to stakes or payments. Indeed, the benefit to the winner is not monetary: "He who rests on No. 77 at London wins the play, shall have the honour of kissing the King of Great Britain's hand and shall be knighted and shall receive the compliments of all the company in regard to his new dignity".

Instructions for other numbers impose delays (miss one or more turns) and send the player off to appropriate destinations. Many of the instructions refer to aspects of commerce of the period. For example, "he who lands on No. 23 Frankfurt must stay one turn, to buy Printer's Black to send to England".

But others are more widely educational: "he who lands on No. 42 Venice must stay one turn, to see the noble bridge called the Rialto; while he who lands on No. $29 \mathrm{Mentz}$ (Mainz) must stay one turn, to learn the art of printing which was found out there by John Faustus in 1440". John Faust was one of Gutenberg's partners but it is surprising that he gets all the credit for the invention of printing from movable type!

31 There are also references to the Hanoverian connection: "he who rests at 28 at Hanover shall by order of the King of Great Britain who is Elector be conducted to No. 54 at Gibraltar to visit his countrymen who keep garrison there"; while the Protestant hatred of the Pope is all too evident: "He who rests at No. 48 at Rome for kissing the Pope's Toe shall be banished for his folly to No. 4 in the cold island of Iceland and miss three turns".

These various instructions succeed in making vivid the characteristics of the places visited but have no resonance with the original Jeu de l'Oie.

The Duval and Jefferys games have few similarities in their selection of aspects considered to be of importance. Passing the Sound (Sund) for entry to the Baltic is featured in both, but generally the games differ considerably, the Jefferys game reflecting strongly the significance of continental European trade in Great Britain's economy.

Jefferys' game was to have few imitators for a decade or so. Thomas Jefferys (no relation to John Jefferys) published another Europe map game in 1768 but thereafter games using a map of Europe were published by several of the major London map publishers: Robert Sayer (1774), John Wallis (1794), and Bowles \& Carver (1790s). Several of these publishers, and others, produced games based on the world map, as well as games based on national maps. This was part of a general proliferation of engraved race games in the England of the $18^{\text {th }}$ and early $19^{\text {th }}$ centuries, covering educational games of many kinds as well as games of amusement, including the Game of Goose itself. 


\section{Games from the Netherlands}

The traditional Jeu de l'Oie has been popular in the Netherlands from an early date. Engraved examples survive from 1640. Existing woodblock versions are of later date but their close similarity to those found in England suggests links going back to the earliest English goose games. Geographical games of local origin (as opposed to local versions of Paris originals) are found from the early 1800 s.

The example selected here is by Mortier and Zoon of Amsterdam, dated 1819. It is entitled "Game of a Journey though the Fatherland for the Youth of the Netherlands", thus declaring its educational intent. It consists of a map of the Netherlands surrounded by a track of 86 spaces, each containing the name of a town or city, and is to be played as a race game in the normal manner.

At first sight, this selection of a game showing a journey through a single nation might seem to contravene the international purposes of the current paper. However, a moment's inspection of the map will show that it includes the territories of Belgium and Luxemburg. When the new Kingdom of the Netherlands was formed in 1815, the Austrian Netherlands (now Belgium) was added, while Luxemburg was a crown Dominion of the Dutch King. In 1830, Belgium was again separated, but between 1815 and 1830 Dutch children had to learn the geography of all three territories, as reflected in this game.

Games on the principle of the Jeu de l'Oie remain popular in the Low Countries to this day, with innumerable variants and styles.

\section{Lithographed games of the $19^{\text {th }}$ century}

The development of lithography in the $19^{\text {th }}$ century enabled the production of highly attractive geographical games using the new technique. An early example in England was The Travellers or a Tour through Europe, published in London by William Spooner in 1842. This is a coloured map of Europe, with vignettes of many of the places to be visited, including sea areas. Lines of latitude and longitude are shown and indeed the game is to be played on the intersections of these lines. Movement of each player's marker is determined by the spin of a four-sided teetotum bearing the letters $\mathrm{N} \mathrm{E} \mathrm{S} \mathrm{W}$ for the points of the compass, to give the direction in which the marker is to be moved, as far as the next intersection. Each player begins from a different starting point and is required to journey to a specified capital city, e.g. the player who starts from Jerusalem must reach Vienna, while from Cairo the aim is to reach St Petersburg, etc. A city is reached by reaching either adjacent point on the same line as the letter denoting that city. Some moves require a player to pay or take from the pool - a player who loses all his initial 20 counters (his "expenses" for the journey) becomes "bankrupt" and must leave the game. A traveller who reaches any capital city (marked by three daggers on the map) must announce the name of the country of which it is capital, or pay a fine of two counters. The first player to reach his or her specified city wins the pool.

This is clearly an educational game. Like the Jeu de l'Oie, it is a game of pure chance, with no skill and no choice of moves. However, unlike that game, it is a two dimensional random walk, rather than a progress along a single track. The main 
purpose of including it here is to make the point that not all geographical race games are unicursal.

41 Another purpose is to show the beautiful effects that could be produced in the medium of lithography. The section shown illustrates geographical features such as the Giant's Causeway, gives vignettes of the main cities and also illustrates topical matters such as the perils of whaling.

42 Lithographed map-based games are found throughout Europe.

Figure 3. Vaderlandsch Reisspel voor die Nederlandsche Jeugd - Mortier en Zoon (1819).

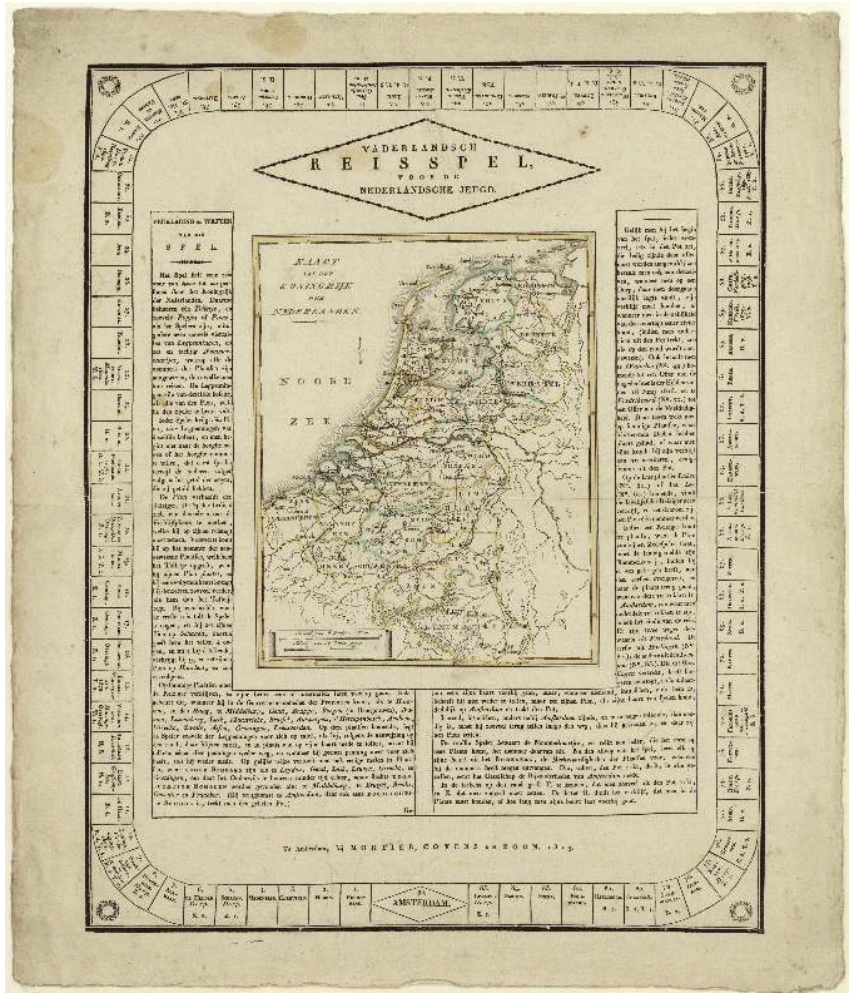


Figure 4. Travellers of Europe - Spooner (1842).

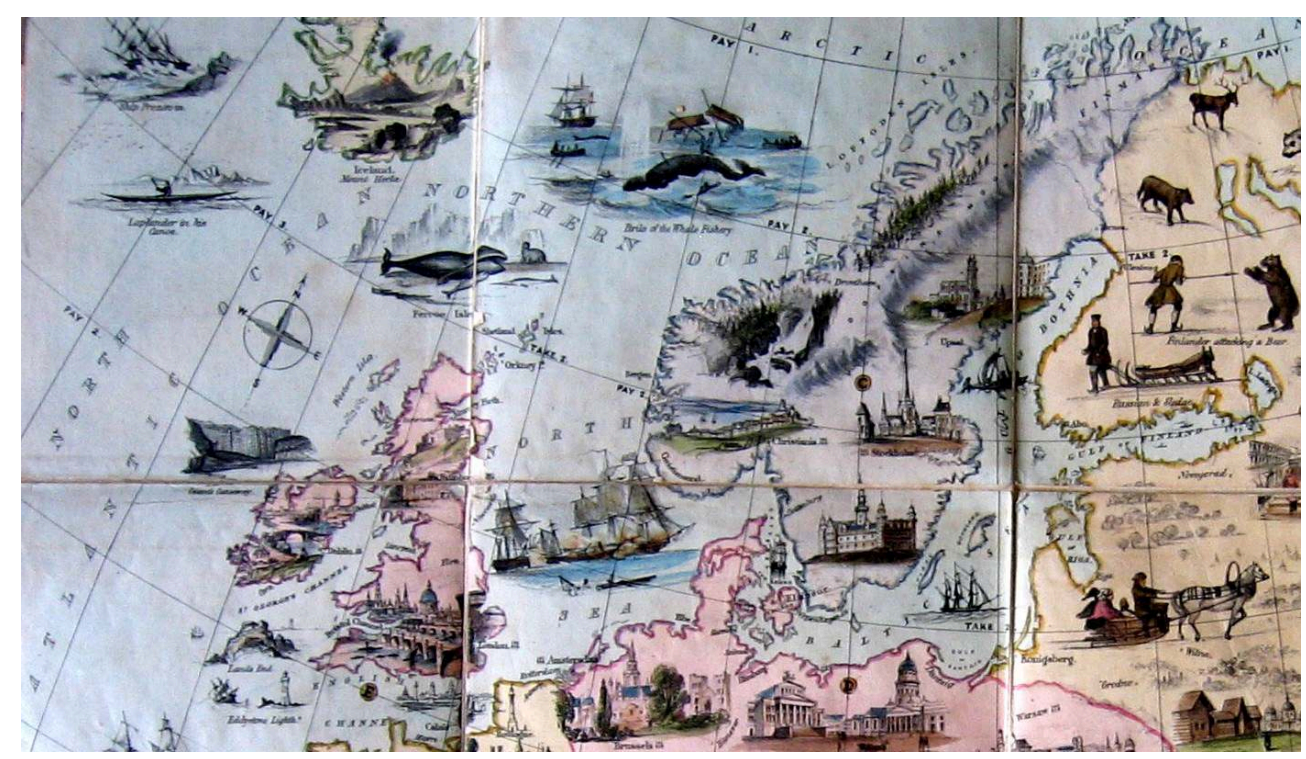

\section{The Twentieth Century} It may seem strange to leave the games of Italy until this point - after all, Italy was the place where, as the Gioco dell'Oca, the Jeu de l'Oie was invented at the end of the $16^{\text {th }}$ century. Though Italy was responsible for many popular "world tour" (Giro del Mondo) games on the principle of the Jeu de l'Oie - lively productions, seldom based on maps, but with attractive coloured views of the places visited - the same principles were not used in the development of map-based games for the teaching of geography. Indeed Mascheroni and Tinti (1981, p.78, present author's translation) comment on the boring nature of some of these games dating from the $18^{\text {th }}$ and early $19^{\text {th }}$ centuries:

44

The information was always of the same kind: the world was divided into four sections. The principal cities were specified. There were notes on economic resources but these were concerned only with gold, diamonds, commerce in porcelain, and silk.

The play was particularly fatiguing since it required repeated reference to a detailed rulebook, specifying the move or payment to be made, unlike the Jeu de l'Oie, where the simple rules were apparent from the face of the game. The use of a complicated rulebook was of course not restricted to Italy - many of the English educational games of the Victorian period, and some of the earlier French, adopted this worthy but stultifying device.

The game selected for description here is of a much later era - the $20^{\text {th }}$ century - when the Italians under Mussolini were at the forefront of enthusiasm for innovation, especially in aeronautics. It shows the voyage in 1926 of the dirigible Norge from its base in Oslo first to Rome then on to the North Pole until its landing in Alaska. The 72space track is shown as series of small numbered circles, supplemented by larger spaces, of which some show scenes from the voyage and others show small maps, on which the path of the Norge is marked. These maps are of no great cartographic quality but are of interest: for example, one marks the aerostation at Pulham Market, in England, now long defunct. 
Figure 5. II Dirigible Norge alla Scoperta della Polo Nord - Marca Stella (1926).

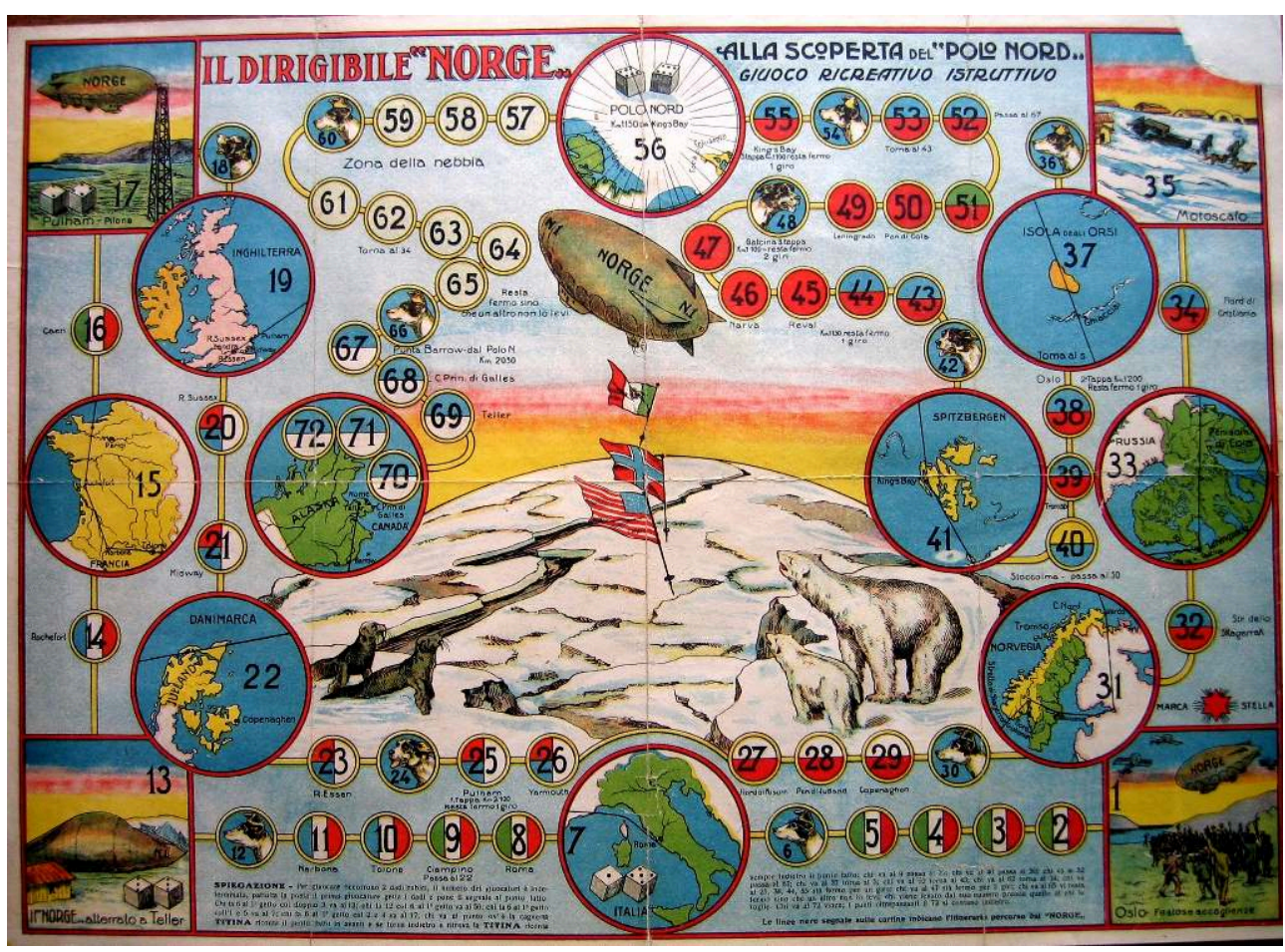

Also of interest is that this is clearly a game based on the Jeu de l'Oie. Here, though, the favourable spaces are marked not with a goose but with a dog, named Titina, the mascot taken on the voyage by Umberto Nobile, its organiser. The dog occurs one in every six spaces (unlike the Jeu de l'Oie where the series of geese are on every ninth space, usually with two such series). However, the characteristic rule of doubling the throw on these spaces is retained.

\section{Advertising, Promotion and Propaganda}

Although they operate at national rather than international level, brief reference must be made to the thousands of race games which were published in $20^{\text {th }}$ century for advertising and promotional purposes, or for politics and propaganda.

An example of a map-based game promoting a product is that offered gratis by the manufacturers of Chartreux table oil in Willems, Belgium - see Van Bost (1990, p.111) for an illustration. It is a crudely drawn map of Belgium, showing the route of a cycle tour beginning at Willems, where the oil is made, and ending at Brussels. Informative details of the towns encountered on route are given but have no playing significance. The rules are a simplified version of the Jeu de l'Oie, where landing on a space marked with a bottle of the oil entitles the player to move on by the amount of the spin. The intention to associate the product with the "good" spaces of the Jeu de l'Oie is obvious.

\section{Touring in Europe}

Some promotional race games, though, were aimed internationally, particularly those for encouraging tourism. Race games designed to attract the tourist are a notable feature of Switzerland and Germany, constituting almost a separate genre. They must 
be presumed to derive from an original different from the traditional Jeu de l'Oie, for their playing features show no resemblances to that game. The track lengths are arbitrary and the rules equally so. In this, they follow the many non-cartographic travel games found in Germany, typified by Post-und-Riesenspiel.

Easy international tourism (as opposed to the aristocratic "Grand Tour" of earlier days) grew out of the technical revolution in travel from the second half of the $19^{\text {th }}$ century, when railways began to make penetration into the mountain ranges relatively convenient. Switzerland was the prototype destination and the Tour of Switzerland the archetypal game. However, it was primarily the German manufacturers who put such games in their catalogues beginning towards the end of that century and continuing well into the $20^{\text {th }}$ : Scholz (Mainz), Sala (Berlin), Spear (Nurnberg and London), Maier (Ravensburg) and Hausser (Ludwigsburg) all produced such games - see Audisio and Schädler (2006), also Kaysel and Etter (1989). Not every one was map-based: the board often consisted of a series of attractive views, reproduced by colour lithography, though a small map might be added as a guide. Again, not all were unicursal race games: there was considerable variety of playing structure, for example the multicursal layout of the railways could be used as a basis - e.g. the Jeu de chemin de fer suisse (Milanesi and Lanari, 2001, p. 95).

The example shown here is a relatively humble production, dating from about 1935 , showing a tour of Germany but intended to promote the use of agricultural chemicals. It represents a land evidently peopled with happy couples in colourful costumes of the region - but to the north a German warship lurks. In fact, this game is a clear reflection of the Third Reich - the game begins in Berlin, with an explicit reference in the text to $21^{\text {st }}$ March 1933 and the opening of the new Reichstag by Hitler. The map shows East Prussia as separated from the rest of Germany by Danzig and the Polish Corridor, legacies of Versailles - but the journey loops across the divide almost as though it did not exist.

These games of travel are of course man-made representations of the areas they cover. It is particularly characteristic of them that they aim to convey messages about that area, whether as publicity or propaganda.

\section{Games based on Plans}

Some "map games" would be better described as being based on plans. These include games based on plans of cities and towns, together with those of even more local or ephemeral significance. These are generally excluded from this paper since they lack an international dimension. However, it may be appropriate to mention that Expo 58 in Brussels - a truly international event of some significance for Europe - gave rise to a race game in its own right, though not one having much to do with the Jeu de l'Oie. 


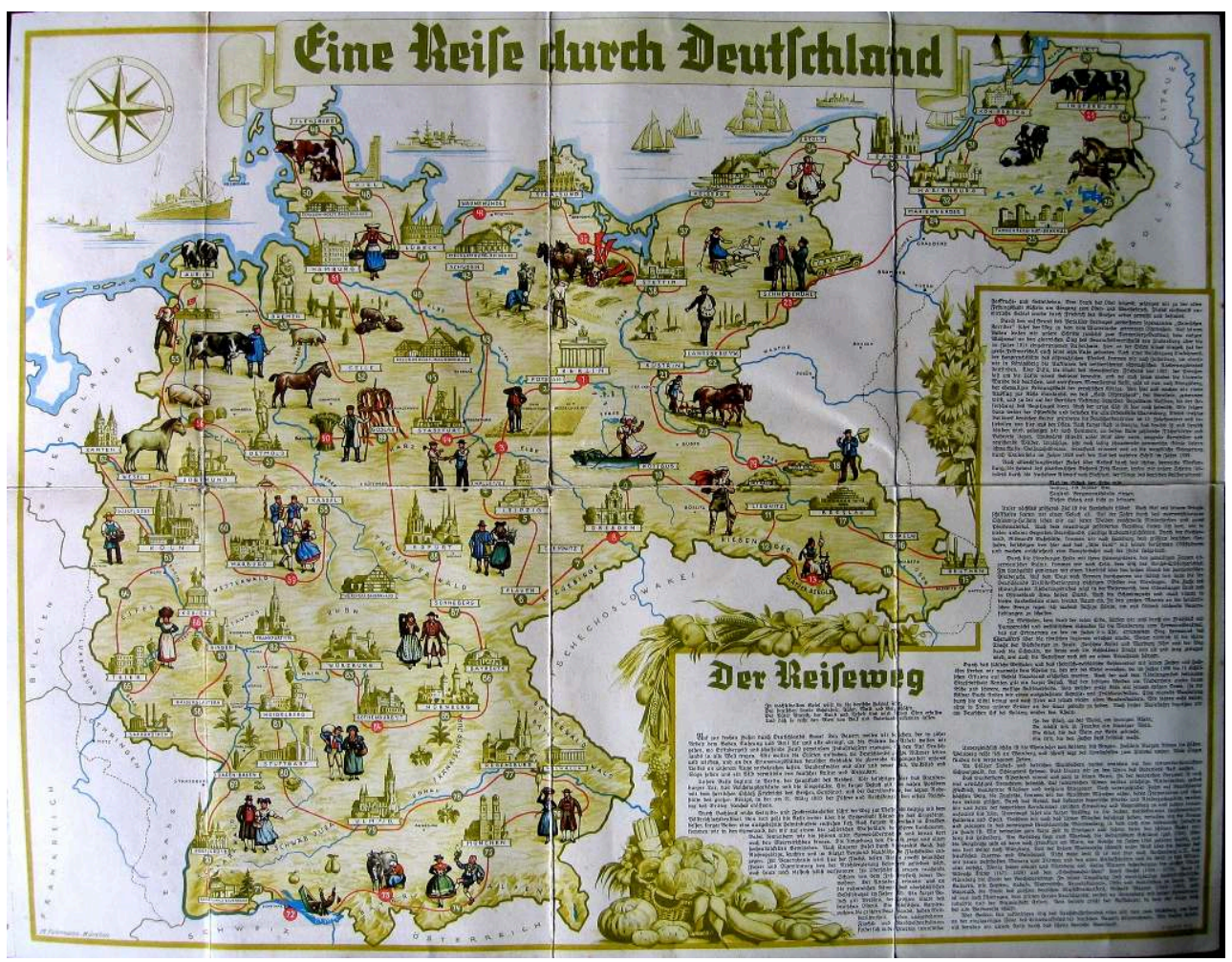

\section{Map Games with a Message}

Maps are representations on a surface, made by humans for human purposes. In fulfilling those purposes, the makers of conventional maps may feel under an obligation to create representations that are, as far as possible, objective and valuefree. No such obligation seems to have occurred to the minds of those creating mapbased games. Their games are full of messages extraneous to the playing purpose: messages that are sometimes overt, sometimes concealed.

To modern European eyes looking at his game of 1662, Duval's patriotism, though perhaps understandable in one so reliant on the patronage of the King of France, seems over-fervent: "France - the eye and pearl of the World", with Europe similarly exalted in relation to the other continents. Yet this patriotic view was enduring: in about 1815, the Paris firm of Basset produced the Jeu Instructif des Peuples et Costumes des Quatre Parties $\mathrm{du}$ Monde et des Terres Australes. This was a game strongly based on the Jeu de l'Oie in which each of the 63 spaces showed a nation of the world, with inhabitants in national dress. The winning space was France, as in the much earlier Duval game - but here the countries of Europe were selected for the favourable "goose" spaces. "Europe is good!" was the message - whereas in contrast New Zealand was chosen for the "death" space on 58, with the legend: "Voyageur prêt à être mangé par les Anthropophages" and a correspondingly graphic illustration.

The Jefferys game of 1759 is likewise overtly patriotic: London is the winning space and references to the Protestant monarchy abound. Here, though, is an element of religious bigotry, evident in the treatment of Rome. 

especially in a historic context. The rules of the game may relate to those of other games and, if so, may carry resonances that go beyond the mere playing process. The games may have distinctive iconographies and are often attractive objects in their own right. Both the social milieu and the commercial market for these games may influence their design and theme. Their effect may be, wittingly or unwittingly, to convey interesting, amusing or disturbing messages about their time and place. This short paper has by no means exhausted these possibilities.

\section{BIBLIOGRAPHY}

AUDISIO A. \& SCHÄDLER U. (2006), Le Montagne per Gioco, Torino, CAI Torino.

BLAU J.L. (1944), The Christian Interpretation of the Cabala in the Renaissance, Columbia, Columbia University Press.

BROWNE T. Sir (1650), Pseudodoxia Epidemica, Ch XII. 
BUIJNSTERS P.J. \& BUIJNSTERS-SMETS L. (2005), Papertoys, Zwolle, Waanders.

CARRERA P. (1617), Il Gioco degli Scacchi, Militello.

D'ALLEMAGNE H.R. (1950), Le Noble Jeu de l'Oie, Paris, Libraire Gründ.

DIETSCH P. (1983), “Variations sur le theme du Jeu de l'Oie”, Vieux Papier, fasc. 290, octobre, pp. 106-120.

DOMINI D. (1999), La Vite e il Vino, Torgiano, Fondazione Lungarotti.

GIRARD A.R. \& QUETEL C. (1982), L'histoire de France racontée par le Jeu de l'Oie, Paris, Balland/ Massin.

GOODFELLOW C. (1991), A Collector's Guide to Games and Puzzles, London, Apple Press.

GRAND-CARTERET J. (1896), “Le Monde vu par l'Image - les Jeux de l'Oie Géographiques”, Journal des Voyages, No. 963, pp. 63-64.

GRAND-CARTERET J. (1896), Vieux Papiers, Vieilles Images, Paris, Le Vasseur.

HIMMELHEBER G. (1972), Spiele - Gesellschaftspiele aus einem Jahrtausend, Deutscher Kunstverlag.

KAYSEL R. \& ETTER M. (1989), Die Schweiz im Spiel, Würenlos, Carlit.

KOHLMANN T. (1978), Wer Spielt Mit?, Berlin, Museum für Deutsche Volkskunde.

MASCHERONI S. \& TINTI B. (1981), Il Gioco dell'Oca, Milano, Bompiani.

MENESTRIER C.F (1704), Bibliothèque Curieuse et Instructive, Trevoux.

MILANESI F. (1995), “Percorsi Italiani di Propaganda”, Charta, November-December, pp. 55-57.

MILANESI F. \& LANARI D. (2001), Il Gioco dell'Oca nei Tempi, Padova, Centrooffset Edizioni.

MURRAY H.J.R. (1952), A History of Board Games Other Than Chess, Oxford, Oxford University Press.

RABECQ-MAILLARD M.M. (1961), Jeux et Jouets d'Autrefois, Paris, Institut Pédagogique National.

SEVILLE A.H. (1999), "Tradition and Variation in the Game of Goose", Board Games in Academia III (Proceedings of Colloquium in Florence), pp.163-174.

SEVILLE A.H. (2001), "Statistics of Enjoyable Race Games", Board Games in Academia V (Proceedings of Colloquium in Barcelona, unpublished: available from the author).

SEVILLE A.H. (2005), "Le Jeu de France - Pierre Duval's Map Game”, Brussels, International Map Collectors Circle, Newsletter, 21, pp. 24-26.

SHEFRIN J. (1999), Neatly Dissected, Los Angeles, Cotsen Occasional Press.

VAN BOST F. (1990), Het Ganzenbord in Vlaanderen, Gent, Koninklijke Bond der Oostvlaamse Volkskundigen.

VON WILCKENS L. (1985), Spiel, Spiele, Kinderspiel, Germanisches Nationalmuseums, Nürnberg.

WHITEHOUSE F.R.B. (1951), Table Games of Georgian and Victorian Days, London, Peter Garnett.

ZOLLINGER M. (2003), “Zwei Unbekannte Regeln des Gansespiels”, Board Game Studies, 6, Leiden University, pp. 61-84. 


\section{ABSTRACTS}

The Jeu de L'Oie (Game of Goose), a unicursal race game played with tokens and dice, is named from the goose symbols on the favourable spaces. Many variants have been developed of the original $16^{\text {th }}$ century Italian game. An important genre, originating in France as an educational aid, is that of geographical games, many being based on maps. The paper discusses the history of cartographical games that have an international dimension within Europe.

Six such games are illustrated, originally published in $17^{\text {th }} \mathrm{C}$ France, $18^{\text {th }} \mathrm{C}$ England, $19^{\text {th }} \mathrm{C}$ Netherlands, $19^{\text {th }} \mathrm{C}$ England (a non-unicursal variant), $20^{\text {th }} \mathrm{C}$ Italy and $20^{\text {th }} \mathrm{C}$ Germany. The rules of each are contrasted with those of the parent game of Goose. Techniques of printing and cartography are compared.

Each game goes beyond simple cartographic representation to convey, through its rules or iconography, a deliberate "message", whether political, commercial or cultural. The games give insights into international relationships, perceptions and misconceptions at various points in the history of Europe.

Le nom "Jeu de l'Oie" (jeu de parcours où l'on déplace des pions en fonction des résultats des dés) provient de la représentation d'une oie dans certaines cases bénéfiques. De nombreuses variantes de ce jeu, qui trouve son origine dans l'Italie du XVI ${ }^{\mathrm{e}}$ siècle, ont été développées. Parmi celles-ci, les jeux géographiques, souvent basés sur des cartes, représentent un genre important, apparu en France en tant que support éducatif.

Cet article examine l'histoire des jeux cartographiques ayant pris une dimension internationale à travers l'Europe.

Nous illustrerons ici six de ces jeux, apparus en France au XVII ${ }^{\mathrm{e}}$ siècle, en Angleterre au XVIII ${ }^{\mathrm{e}}$, aux Pays-Bas et en Angleterre au XIX (dans ce dernier cas il s'agit d'une variante non unicursale), en Italie et en Allemagne au XX $\mathrm{XX}^{\mathrm{e}}$ siècle. Les règles de ces jeux sont mises en contraste avec celles de leur ancêtre. Nous comparerons également les techniques d'impression et les cartographies.

Chacun des jeux dépasse la simple représentation cartographique pour apporter, par ses propres règles ou son iconographie, un "message" délibéré: politique, commercial ou encore culturel. Ils donnent également un aperçu des relations internationales, perceptions ou idées erronées à différents moments de l'histoire européenne.

\section{INDEX}

Keywords: board game history, dice, Europe, France, Germany, Netherlands, England, Italy, cartography, printing, propaganda, advertising, culture, international relations, commerce, trade, 16th, 17th, 18th, 19th, 20th century

Mots-clés: histoire des jeux de société, dés, Europe, France, Allemagne, Pays-Bas, Angleterre, Italie, cartographie, imprimerie, propagande, publicité, culture, relations internationales, commerce, XVIe, XVIIe, XVIIIe, XIXe, XXe siècles

\section{AUTHOR}

\section{ADRIAN SEVILLE}

City University, London, UK, Adrian.Seville@btopenworld.com 